\title{
ENERGY MANAGEMENT FOR PV/BATTERY STANDALONE PHOTOVOLTAIC SYSTEM
}

\author{
Evren ISȘEN*, Ömer KOÇHAN
}

Bandırma Onyedi Eylül University, Faculty of Engineering and Natural Sciences, Electrical Engineering, Bandırma, Türkiye

\begin{tabular}{l} 
Keywords \\
\hline Energy Management, \\
Standalone System, \\
Photovoltaic System, \\
Inverter Control, \\
DC-DC Converter Control.
\end{tabular}

\begin{abstract}
In this study, a simulation of a standalone photovoltaic system with a power of 4.2 $\mathrm{kW}$ was carried out. In the system, which has a total of 20 photovoltaic panels, the perturb \& observe maximum power point tracking method was used, and photovoltaic panel control was performed by a DC-DC boost converter. Thus, maximum power could be drawn from the panels continuously despite changing weather conditions. Batteries are used to store energy in this system, which operates independently from the network. The battery group with a total voltage level of 300V was charged and discharged by a bidirectional DC-DC converter. With variable radiation values, variable power generation was provided in the panels, and energy flow control in the system was realized. The required energy flow in the system has been controlled depending on the amount of energy generated from the photovoltaic panels, the energy demanded by the load and the state of charge of the battery pack. The energy in the dc bus regulated at $400 \mathrm{~V}$ voltage level fed the load with the help of a single-phase inverter. The system was operated in five different modes, and performance of the system was introduced.
\end{abstract}

\section{ŞEBEKEDEN BAĞIMSIZ FOTOVOLTAİK PANEL/AKÜ SİSTEMINIIN ENERJi YÖNETIMI}

\begin{tabular}{l}
\hline Anahtar Kelimeler \\
Enerji Yönetimi, \\
Şebekeden Bağımsız Sistem, \\
Fotovoltaik Sistem, \\
Inverter Kontrol, \\
DC-DC Dönüştürücü Kontrol.
\end{tabular}

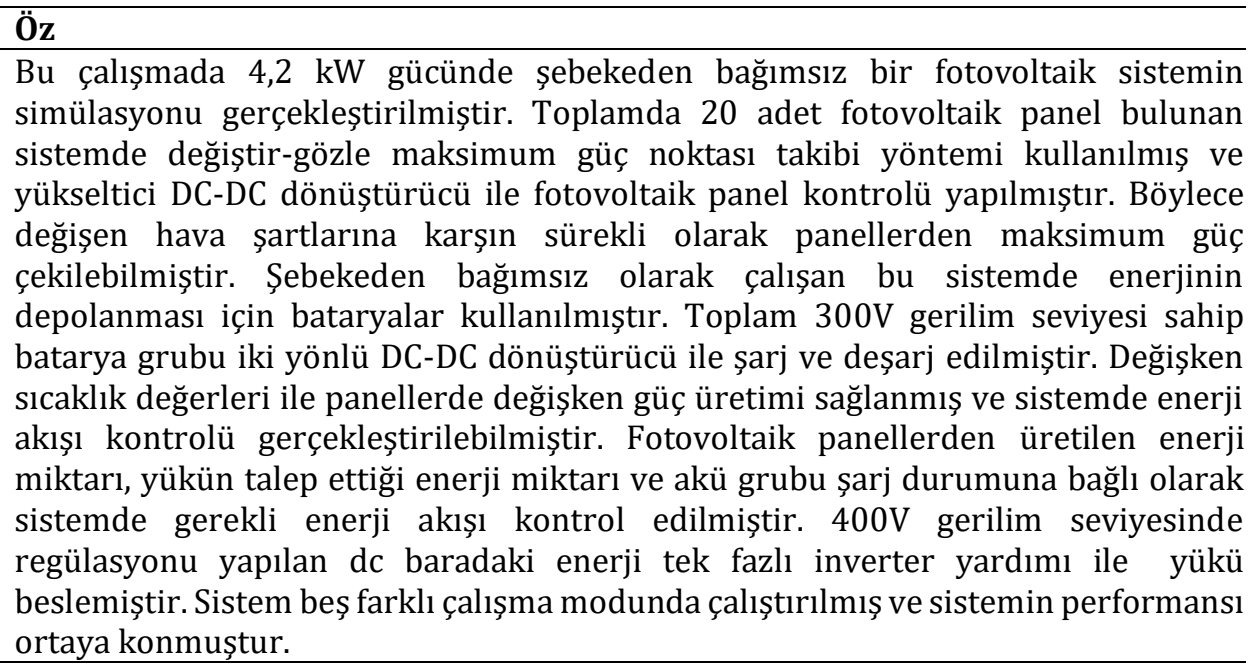

Alıntı / Cite

İşen, E., Koçhan, Ö., (2021). Energy Management For Pv/Battery Standalone Photovoltaic System, Journal of Engineering Sciences and Design, 9(2), 414-424.

\begin{tabular}{l|l}
\hline Yazar Kimliği / Author ID (ORCID Number) & Makale Süreci / Article Process
\end{tabular}

E. İşen, 0000-0002-3107-9255 $\quad$ Başvuru Tarihi / Submission Date

Ö. Koçhan, 0000-0003-2377-1986

Kabul Tarihi / Accepted Date

Yayım Tarihi / Published Date

27.03.2021

04.05 .2021

20.06.2021

\footnotetext{
*ilgili yazar / Corresponding author: eisen@bandirma.edu.tr, +90-266-606-3526
} 


\section{Introduction}

While the use of renewable energy systems is increasing rapidly in the world, photovoltaic (PV) systems have the largest share in this increase. According to 2019 data, the total installed power of photovoltaic systems in the world is $627 \mathrm{GW}$. China has the highest share with an installation of $204.37 \mathrm{GW}$. When the annual installations are examined, it is seen that the photovoltaic systems are more than the wind energy systems, especially in terms of the system power installed since 2016 (IEA, 2020).

Photovoltaic systems are divided into two groups as grid-connected and standalone systems. Grid-connected systems are rather installed in large areas, three-phase and high power capacities (Isen and Bakan, 2018). In addition, single-phase grid-connected photovoltaic systems are installed in roof applications (Rasedul and Mekhilef, 2017). These systems do not have an energy storage unit because the generated energy is directly transferred to the grid. Revenue can be obtained from the produced energy by given to the network. Standalone systems are applied in various fields such as domestic, agricultural, lighting, animal farm and fishery applications, especially in rural areas where there is no electricity distribution system (Al-Waeli and Mahdi, 2017; Sunaryo vd., 2019; Cubukcu and Colak, 2013; Bayrak and Lebeli, 2011; Naktamna vd., 2020). Due to the fact that photovoltaic panels are affected by the radiation and temperature values of the environment and therefore cannot produce energy at all hours of the day, a storage unit consisting of batteries is used in these systems. In addition, wind turbines are also used as an additional energy source in these systems, and hybrid energy systems are created (Arikan vd., 2019). Energy reliability and continuity are among the most important points when designing these energy systems (Kekezoglu vd., 2013). Even enough energy cannot be produced in some or any of the renewable energy sources, the system must continue to operate and feed the load. This can be succeeded with effective source and battery sizing. Furthermore, photovoltaic array tilt angle and orientation are important to increase more energy (Durusu vd., 2020).

Energy control in photovoltaic systems is provided by power electronic converters. In high-power grid-connected systems, the energy generated by the inverter located at the output of the panel group is transferred to the grid. Energy transfer can be done with central, array and AC module inverters (Kouro vd., 2015). Depending on the connection structure of the photovoltaic panels, the appropriate inverter type is used. The produced energy is directly transferred to the grid via an inverter. In standalone systems, there is a DC-DC converter at the output of the photovoltaic panels, and the panel power is controlled by the converter. Maximum power point tracking (MPPT) is performed with the help of it. Panel power is transferred to DC bus by the converter. The energy in the DC bus is converted into AC energy by an inverter, and the load is fed. If the energy generated from photovoltaic panels is more than the demand of the load, it is sent to the battery bank that is a storage element in the system. A bidirectional DC-DC converter is used between DC bus and battery bank. The bidirectional operation feature of this converter enables energy to be transferred from the panels to the battery bank or from the battery bank to the load. Depending on the energy balance in the system, the control algorithm provides bidirectional flow of energy (Gaurav vd., 2015). There are also structures that the battery bank power is not controlled. In the structure, there is not a DC-DC converter.

In this study, a photovoltaic system with power of $4.2 \mathrm{~kW}$ consisting of 20 panels was simulated. In the system, the panel output was controlled by a boost DC-DC converter. The MPPT was achieved by the perturb \& observe (P\&O) method. A bidirectional DC-DC converter was used in front of the battery bank in order to store the energy generated in the panels or to transfer the stored energy to the load when it is necessary. Thus, the battery bank was charged and discharged in control depending on the energy balance in the system. The energy in the DC bus was converted to AC energy with a single phase inverter to feed the load. In order to examine different operating conditions, the radiation values of the environment was changed, and the production and consumption balance in energy was differentiated. Thus, the performance of the system in different conditions was examined. The simulation study showed that, depending on the balance of energy production and consumption, some of the energy generated from the panel was transferred to the load, while the remaining part could be stored in batteries. When the amount of energy produced could not meet the load demand, the battery bank was activated to meet the remaining energy demand, and finally, when the energy production in the panels stopped at night, the load was completely fed from the batteries. The battery unit got overcharged and fully-discharged depending on the energy balance. It causes that PV panels were disconnected from the system, and the system stopped working, respectively.

\section{System Components}

In the photovoltaic system under study, photovoltaic panels as an energy source, a boost DC-DC converter in panel energy control, battery bank as an energy storage unit, and bidirectional DC-DC converter for energy control of 
battery bank and finally single-phase inverter to feed the load at the output is used. In this section, the details were given about the topologies and control algorithms used.

\subsection{Photovoltaic Panel}

Photovoltaic panels are components that generate electrical energy depending on the radiation and temperature value. Panels consist of a large number of cells. Cells are low voltage elements, and they are connected in series to increase the voltage and power level of the panel (Tarabsheh vd., 2017). In simulation studies, photovoltaic panels can be operated with ready-made models in the software used, as well as mathematically modeled. In this study, 1STH-215-P ready-made model in Matlab / Simulink environment was used. Electrical characteristics of the $215 \mathrm{~W}$ output power panel are given in Table 1.

Table 1. Technical details of PV panel

\begin{tabular}{|l|l|}
\hline \multicolumn{1}{|c|}{ PARAMETERS } & \multicolumn{1}{c|}{ VALUE } \\
\hline Maximum power $\left(\mathrm{P}_{\max }\right)$ & $213.15 \mathrm{~W}$ \\
\hline Open circuit voltage $\left(\mathrm{V}_{\mathrm{oc}}\right)$ & $36.3 \mathrm{~V}$ \\
\hline Short circuit current $\left(\mathrm{I}_{\mathrm{sc}}\right)$ & $7.84 \mathrm{~A}$ \\
\hline Maximum power voltage $\left(\mathrm{V}_{\mathrm{mpp}}\right)$ & $29 \mathrm{~V}$ \\
\hline Maximum power current $\left(\mathrm{I}_{\mathrm{mpp}}\right)$ & $7.35 \mathrm{~A}$ \\
\hline
\end{tabular}

Photovoltaic cells can be modelled in different topologies such as a single-diode and two-diode. The photovoltaic cell in the Simulink environment is modeled as a single diode. The circuit in the modeled photovoltaic panel is shown in Figure 1. The model includes a current source, and its value varies depending on radiation and temperature. In the model, there is a current source at the input as the energy source, while there are two resistors in series and parallel at the output. There is also a diode connected inversely parallel to the source between the source and the parallel resistor. The model takes its name from the diode. In the simulation studies, the readymade model in Matlab / Simulink environment can be used as well as the mathematically diode model (Isen and Kochan, 2020).

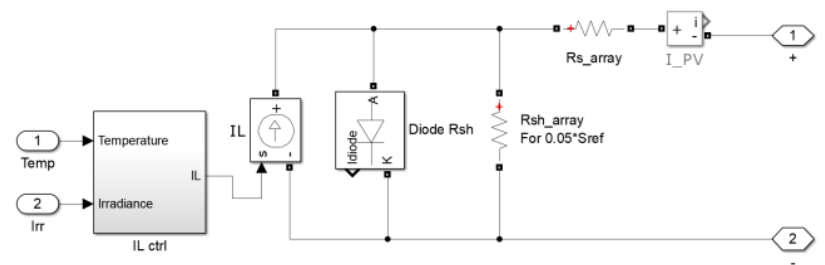

Figure 1. Single-diode model of photovoltaic cell

\subsection{DC-DC Boost Converter}

In the developed standalone system, a boost type DC-DC converter is used at the panel output. The output voltage of the photovoltaic panels is applied to the input of the boost converter as shown in Figure 2. The converter transfers the current that it is drawn from the panel and injected to the DC bus. While doing this, it controls the power drawn from the panel, additionally. As the maximum power value of the panel changes with the variable radiation, the power drawn from the panel is controlled using the perturb \& observe algorithm.

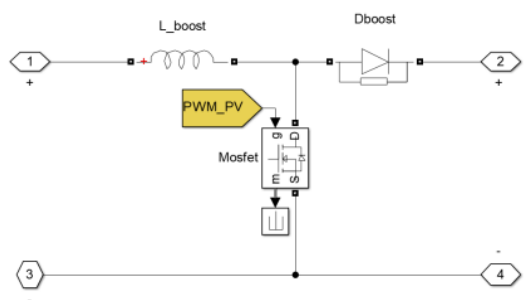

Figure 2. Boost type DC-DC converter

The P\&O algorithm used in controlling the power drawn from the panel works depending on the change of panel power and voltage. The instantaneous power between the two measurements of instantaneous current and voltage is calculated, and depending on the two instantaneous power calculations, power difference is calculated. Likewise, after calculating the voltage variation between the two measurements, it is decided to increase or 
decrease the panel output voltage depending on these two values, and appropriate switching signals are produced. This process is repeated until the maximum power point is determined. In the study, the algorithm is written in code, and the Matlab function block is used as seen in Figure 3 (Isen and Sengul, 2020).

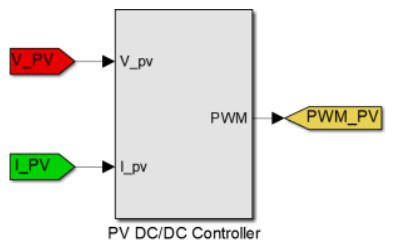

Figure 3. Control of photovoltaic DC-DC converter

\subsection{Bidirectional DC-DC Converter}

Since the developed photovoltaic system is grid-independent, batteries are used as an energy storage unit. The energy drawn from the panels is transferred to the load and batteries depending on the power balance in the system. If adequate energy is not produced from the panels, the energy stored in the battery is transferred to the load. In other words, bidirectional power flow occurs in the converter used in battery control. Therefore, bidirectional DC-DC converter is used in battery current control. The control algorithm of the DC-DC converter shown in Figure 4 is based on DC bus voltage regulation. Bidirectional DC-DC converters are used in photovoltaic and electric vehicle applications to control the power of battery (Jayachandran and Ravi, 2019; Melo vd., 2018).

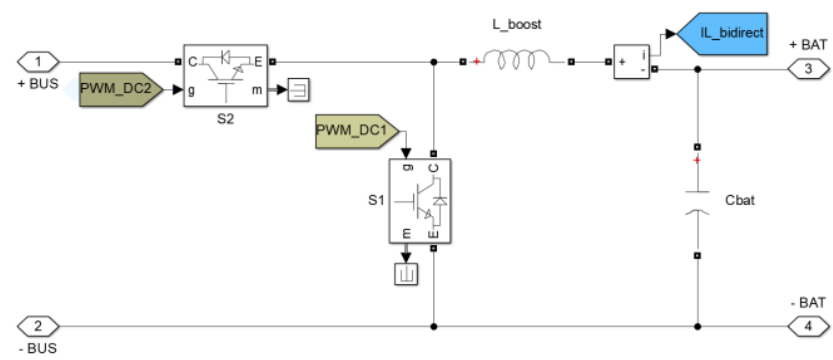

Figure 4. Bidirectional DC-DC converter

Figure 5 shows the control algorithm of the bidirectional DC-DC converter. DC bus voltage is regulated by the battery current. Depending on the DC bus voltage error value, the inductance current reference is generated, and DC bus regulation is provided by the current control. Depending on the power balance in the system, the DC bus voltage can be lower or higher than the reference value. Depending on this situation, the reference inductance current changes direction. DC bus voltage increases at the moments when the energy generated in the panels exceeds the load demand. When the voltage exceeds the reference value, current is drawn from the DC bus to reduce the voltage, and the battery is charged. At moments when the load energy demand is higher than the produced value, the DC bus voltage decreases and falls below the reference value. In this case, energy is drawn from the battery and transferred to the DC bus. Thus, the battery discharges, and the current changes direction.

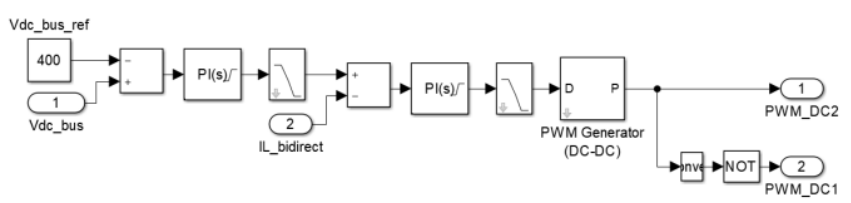

Figure 5. Control algorithm of bidirectional DC-DC converter

\subsection{Single Phase Full-Bridge Inverter}

Since the developed system feed a single phase load, a single phase full-bridge inverter is used at the output of the system (Najeeb vd., 2017). In the single phase inverter shown in Figure 6 , an LC filter is used at the output. The filter attenuates the high order harmonics of the inverter output voltage and provides the voltage needed by the load. Since the inverter regulates the output voltage, as seen in Figure 7, the input reference value of the control algorithm is the load voltage. The inductance current reference is generated by the DC bus voltage error, and the inductance current is controlled depending on the reference. Thus, the desired AC voltage is produced at the output. 


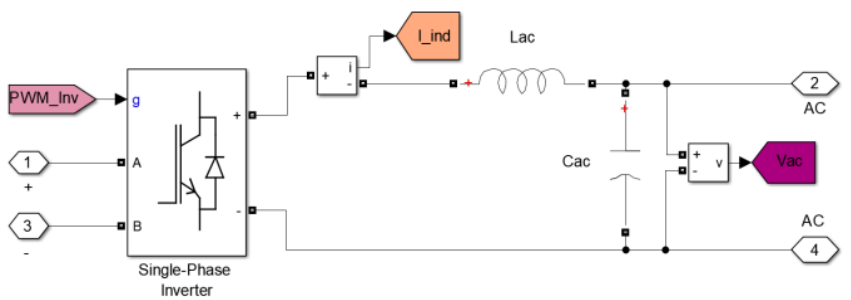

Figure 6. Single phase full-bridge inverter

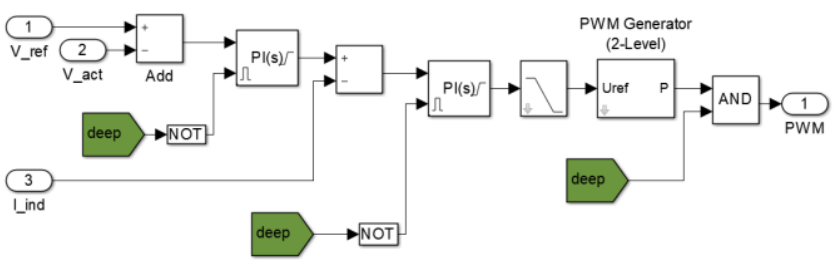

Figure 7. Control algorithm of the inverter

\section{Simulation Results}

The simulation circuit of the developed system is given in Figure 8. Simulation is carried out in Matlab / Simulink environment. A panel array consisting of 1STH-215-P model 20 photovoltaic panels with $215 \mathrm{~W}$ power is used in the simulation. Thus, the input power of the system is designed as $4.2 \mathrm{~kW}$. In the simulation study, the panel output power is changed by changing the radiation, and the dynamic and steady state response of the system is examined. DC-DC converter using P\&O algorithm at the output of the panel array, batteries as energy storage unit, bidirectional DC-DC converter controlling charge-discharge current between DC bus and battery, and a single phase full-bridge inverter that produces load voltage at the output are used. Different operating conditions have been established to examine the steady state, dynamic response and energy flow control performance of the system. The performance of the system in different operating modes is examined by changing the energy balance of the system by making changes in photovoltaic panel power by change of radiation and load power. The operating modes that occur depending on the energy balance are shown in the Table 2 . There are five different operating modes, and the illustration of the operating modes are given Figure 9.

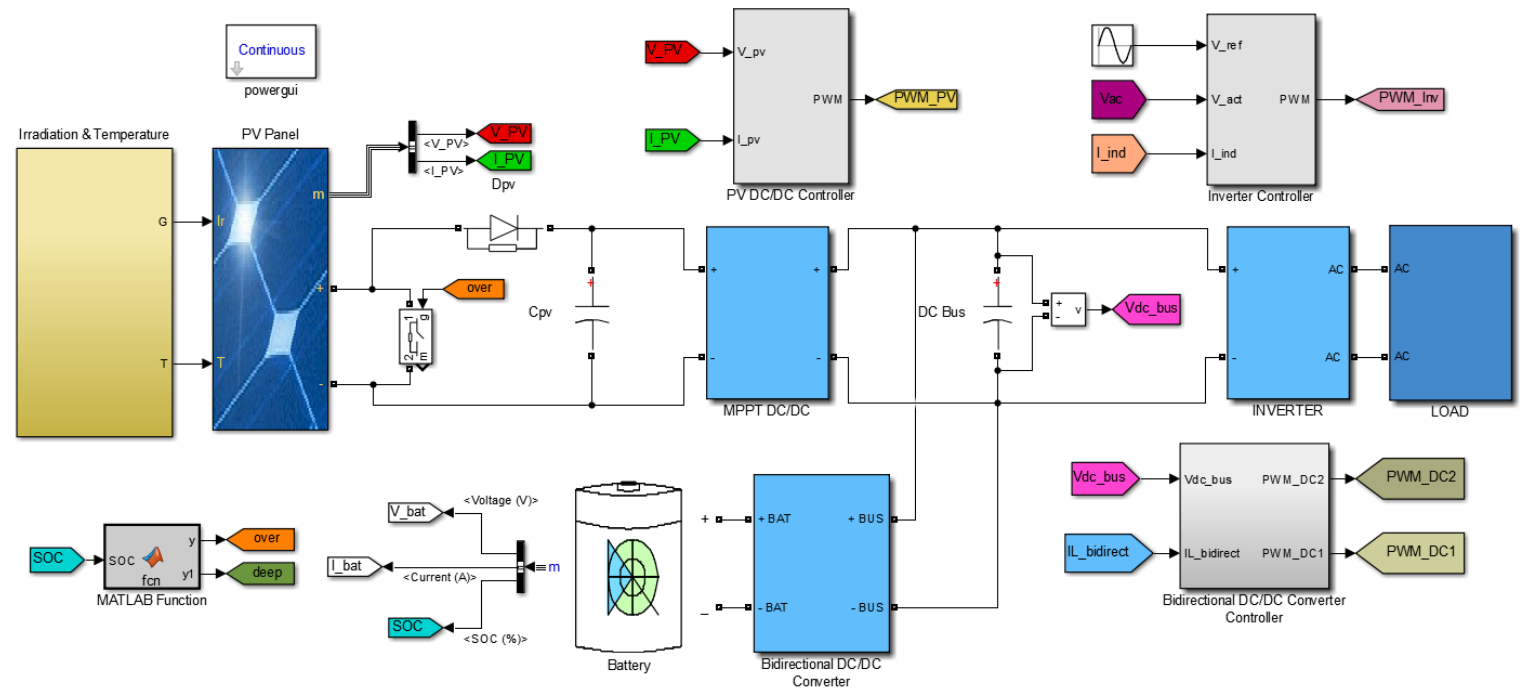

Figure 8. Simulation circuit of the developed system

Table 2. Operating modes

\begin{tabular}{|l|l|}
\hline MODES & \multicolumn{1}{|c|}{ EXPRESSION } \\
\hline Mode 1 & $\mathrm{P}_{\mathrm{pv}}>\mathrm{P}_{\text {load }}$, battery charges $\left(\mathrm{P}_{\mathrm{bat}}<0\right)$ \\
\hline Mode 2 & $\mathrm{P}_{\mathrm{pv}}<\mathrm{P}_{\text {load }}$, battery discharges $\left(\mathrm{P}_{\mathrm{bat}}>0\right)$ \\
\hline Mode 3 & $\mathrm{P}_{\mathrm{pv}}=0, \mathrm{P}_{\text {load }}=\mathrm{P}_{\text {bat }}$, battery discharges, $\left(\mathrm{P}_{\text {bat }}>0\right)$ \\
\hline Mode 4 & $\mathrm{P}_{\mathrm{pv}}=0, \mathrm{P}_{\mathrm{bat}}=\mathrm{P}_{\text {load }}$, battery overcharged $\left(\mathrm{P}_{\text {bat }}>0\right)$ \\
\hline Mode 5 & $\mathrm{P}_{\mathrm{pv}}<\mathrm{P}_{\text {load }}$, battery fully discharged $\left(\mathrm{P}_{\mathrm{bat}}>0\right)$ \\
\hline
\end{tabular}




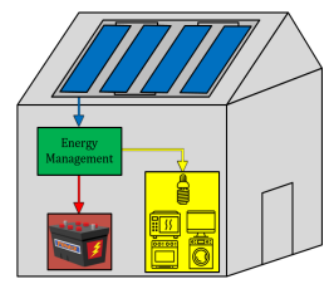

(a)

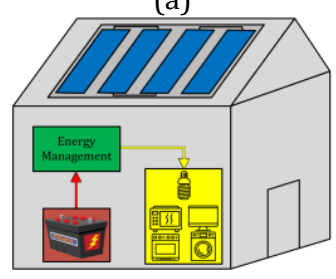

(c)

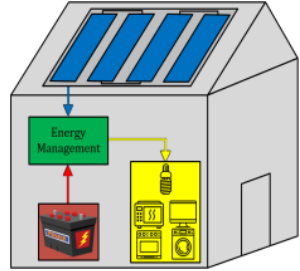

(b)

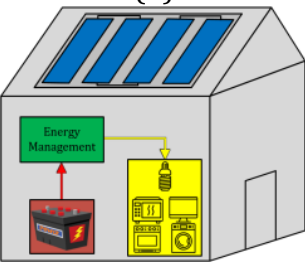

(d)

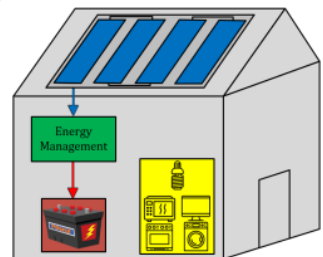

(e)

Figure 9. Operation modes of the system (a): Mode 1, (b): Mode 2, (c): Mode 3, (d): Mode 4, (e): Mode 5

\subsection{Mode $1\left(P_{p v}>P_{\text {load }}, P_{\text {bat }}<0\right)$}

In this operating mode, the power generated by the panels is more than the power demanded by the load. Therefore, the bidirectional DC-DC converter transfers the excess power to the battery. Power flow of the system is seen in Figure 9(a). The power variations of the system are seen in Figure 10(a). In region 1, the system operates in stable. When the difference between the generated power and the load power decreases, the DC bus voltage decreases, and in this case the bidirectional DC-DC converter regulates the DC bus voltage by reducing the charge current. This state can be seen is seen in region 2 and region 3 . While the system is in balance in region 1 , as seen in region 2, the panel output power decreases and the load power increases in region 3 . In both cases, the difference between the generated power and the load power is decreasing. As seen in Figure 10(b), DC bus voltage begins to decrease in power changes in region 2 and region 3 , but battery current is increased by the bidirectional converter as seen in Figure 10(c) to regulate the DC bus voltage. In region 4, the generated power at the same load power increases, and the DC bus voltage rises up. In this case, the battery current increases, and the DC bus voltage returns to the reference value by decreasing. As seen in Figure 10(d), state-of-charge value of battery unit increases rapidly because PV power is always higher than the load power. The only slope of the SOC\% changes depending on the state of power balance.

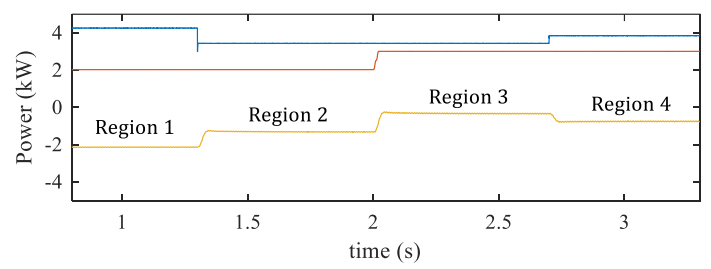

(a)

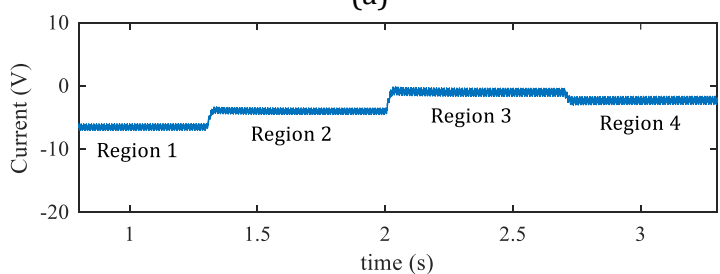

(c)

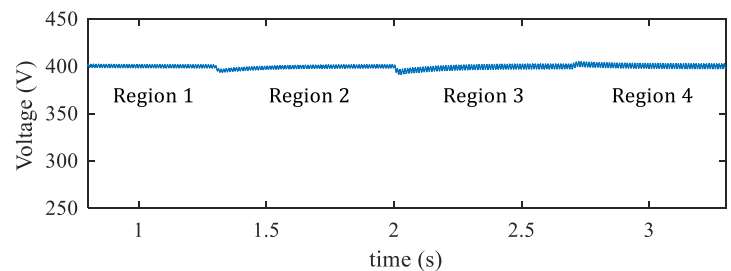

(b)

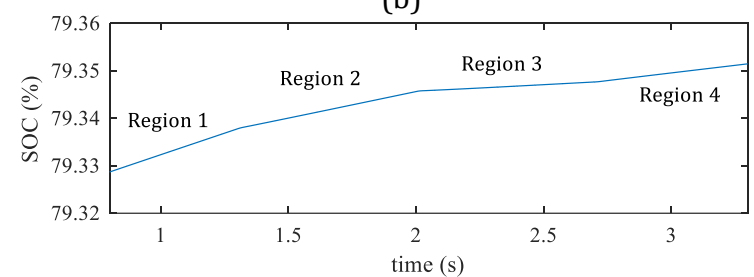

(d)

Figure 10. Mode 1 electrical quantities variations (a): Power variations of the system (blue: PV power, red: load power, yellow: battery power), (b): DC bus voltage, (c): Battery current, (d): State-of-charge of battery unit 


\subsection{Mode $2\left(\mathrm{P}_{\mathrm{pv}}<\mathrm{P}_{\text {load }}, \mathrm{P}_{\mathrm{bat}}>0\right)$}

In this operating mode, the generated power by the panels is less than the power demanded by the load. In this case, the energy needed by the load is met from the DC bus, and the DC bus voltage decreases. A bidirectional DCDC converter that regulates the DC bus voltage is activated, and draws current from the battery to increase the DC bus voltage and feeds it to the DC bus. So the battery discharges. In this mode, energy flows in opposite direction according to operating mode 1 .

In Figure 11, the waveforms show the mode 2 operation principle. Before region 1, mode 1 is active. Region 1 starts with the change of power balance that PV power is lower than the load power as seen in Figure 11(a). In region 2, load power increases while PV power keeps constant. The difference between two power values rises up. In contrast to region 2, PV power increases while load power keeps constant in region 3. The PV power is higher than load power as in other regions, however the battery power decreases because of decrease in power difference. As seen in Figure 11(b), DC bus voltage is regulated in each region. While battery current is negative in mode 1 , it changes direction to positive. It is seen in Figure 11(c). While battery charges in mode 1, it discharges in mode 2. It can be seen with SOC\% variation in Figure 11(d).

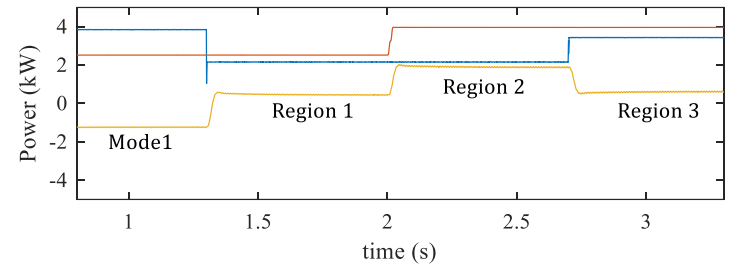

(a)

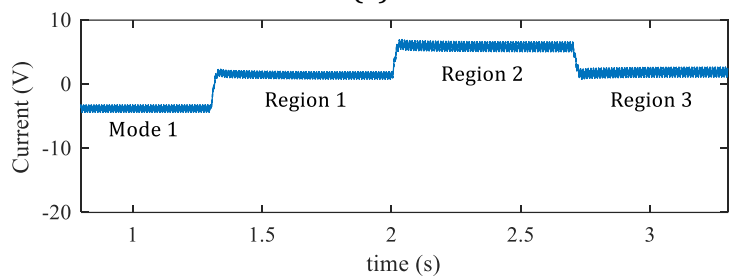

(c)

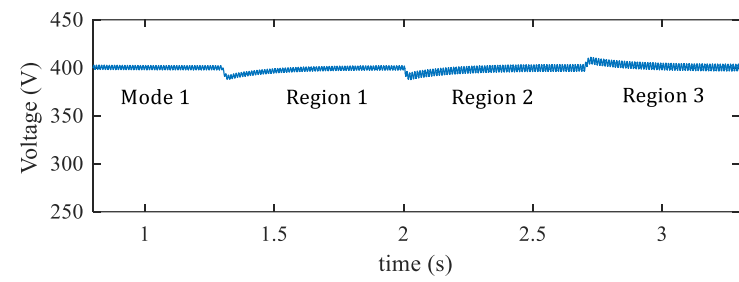

(b)

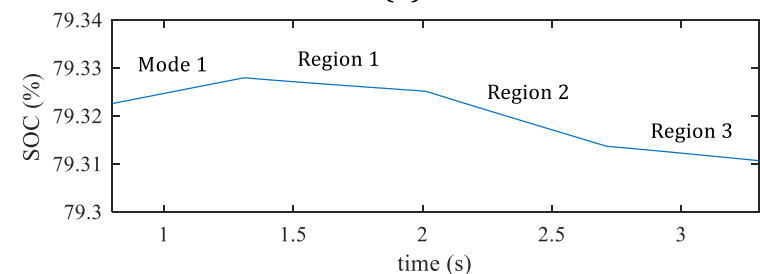

(d)

Figure 11. Mode 2 electrical quantities variations (a): Power variations of the system (blue: PV power, red: load power, yellow: battery power), (b): DC bus voltage, (c): Battery current, (d): State-of-charge of battery unit

\subsection{Mode $3\left(P_{p v}=0, P_{l o a d}=P_{b a t}, P_{b a t}>0\right)$}

In this mode, power demand of the load is supplied from battery unit completely because PV panels could not produce power in nights because of very low radiation. Battery unit discharges, and the stored energy feed s the load. As seen in Figure 12(a), PV power goes down to zero after mode 2 in region 1, and battery power is being equal to load power until the end of region 2. The controller of bidirectional DC-DC converter regulates the DC bus voltage in two transitions as seen in Figure 12(b). While load power is supplied from PV panels and battery unit in mode 2, it is supplied only from battery unit in mode 3. Figure 12(c)shows the battery current that flows positive direction. Since PV panels does not produce power in region 1 and 2, battery discharge current increases. Thus, charge level of battery unit decreases as seen in Figure 12(d). Depending on the current value, rate of discharge increases. 


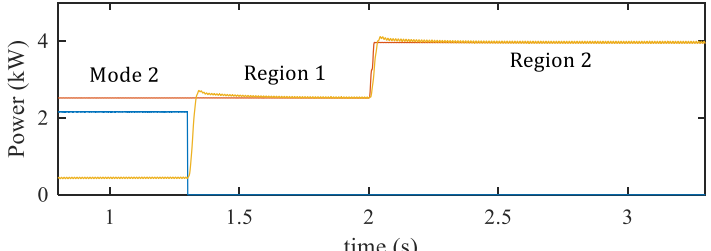

(a)

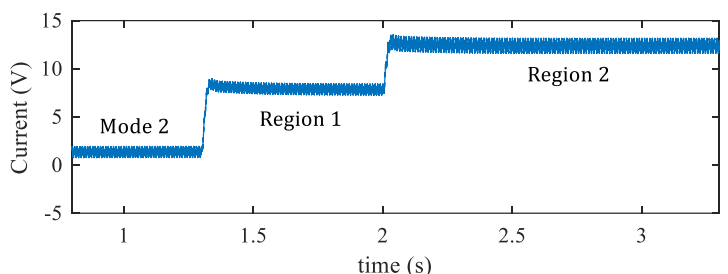

(c)

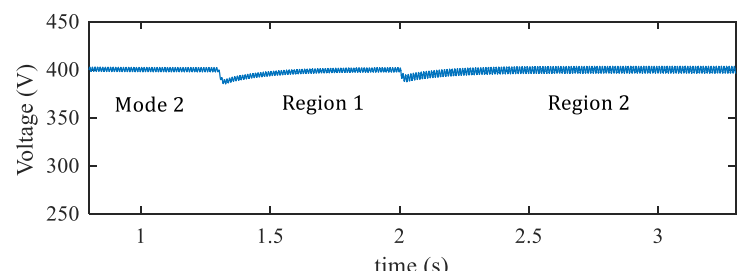

(b)

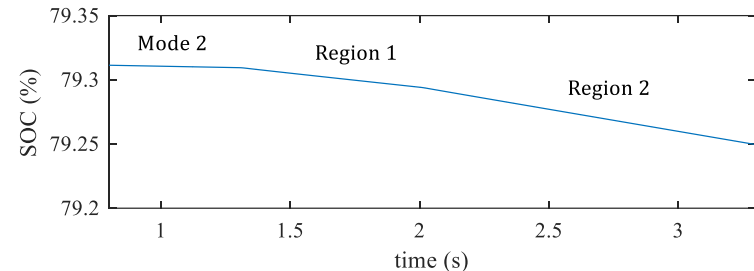

(d)

Figure 12. Mode 3 electrical quantities variations (a): Power variations of the system (blue: PV power, red: load power, yellow: battery power), (b): DC bus voltage, (c): Battery current, (d): State-of-charge of battery unit

\subsection{Mode $4\left(P_{p v}>P_{l o a d}\right.$ overcharged $\left.P_{b a t}<0\right)$}

If the time interval that the energy generated by the photovoltaic panels is more than the energy consumed in increases, the battery voltage rises continuously, and the battery becomes overcharged. In this case, in order to prevent the battery from being damaged, the panels are deactivated, and the load begins to be fed directly from the batteries. Thus, the battery discharges, and battery voltage level is reduced. When the battery voltage drops to the specified value, the panels are reconnected to the system, and the system operation switches to a different operating mode depending on the energy balance. However, in this mode, although there are ambient conditions where power can be generated from the panels, PV panels are disabled. Therefore, the system efficiency decreases. Because of feeding the load from just battery unit, battery voltage starts decreasing, and PV panels are reconnected to the system when battery unit voltage drops down to reconnection level.

The simulation results of the system are given in Figure 13. While the system operates in mode 1, the \%SOC value of the battery unit reaches $100 \%$ as seen in Figure 13(d). In order to protect the battery unit, PV panels are disconnected from the system. It can be seen in Figure 13(a) that PV power drops to zero. Because of changing in power balance, DC bus voltage starts dropping but controller regulates the voltage to set value of $400 \mathrm{~V}$ in region 1 as seen in Figure 13(b). Figure 13(c) shows the battery current waveform. In region 1, battery unit current flows opposite direction, and it discharges. Therefore, SOC\% value starts decreasing as seen in Figure 25. In the simulation study, the SOC\% value of reconnection of PV panels is set to $99.9 \%$. When it drops to set value, PV panels are reconnected to the system, and the load power is shared between PV panels and battery unit as seen in region 2.

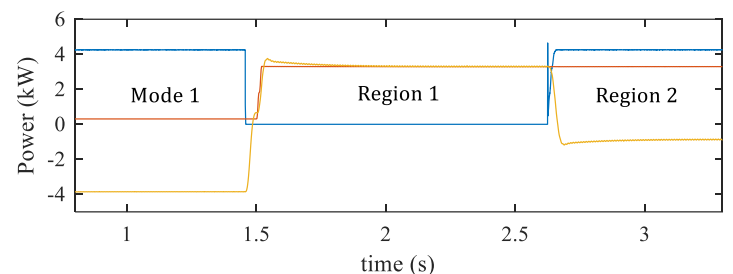

(a)

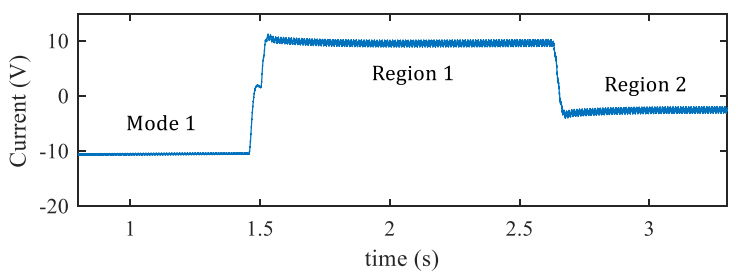

(c)

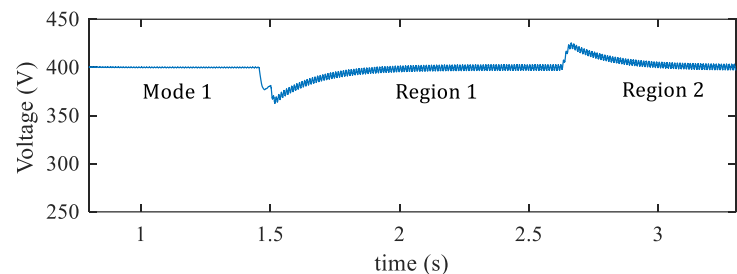

(b)

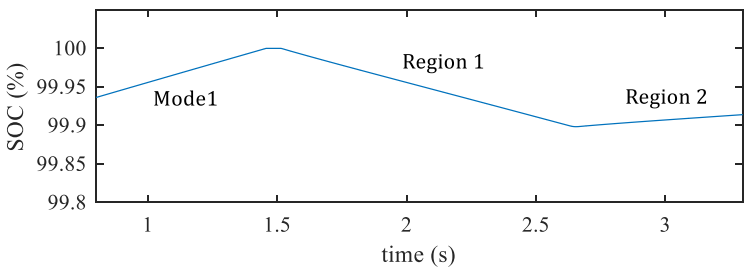

(d)

Figure 13. Mode 4 electrical quantities variations (a): Power variations of the system (blue: PV power, red: load power, yellow: battery power), (b): DC bus voltage, (c): Battery current, (d): State-of-charge of battery unit 


\subsection{Mode 5 (Ppv<Pload, fully discharged Pbat $>0$ )}

When the power demand of the load is more than the produced power, the required power is supplied from the battery unit, and the batteries discharge. If this situation continues for a long time, the deep discharge level can be reached with decreasing the battery voltage. Therefore, battery discharge is stopped. In other words, the system stops working, and the load remains without energy. This is due to the system sizing error or the occurrence of some unforeseen environmental conditions. In order to avoid this situation, larger capacity batteries should be placed in the system. As load is disconnected from the system, the produced PV power is transferred to the battery unit, therefore battery voltage increases. When it is reached to the reconnection voltage level, battery unit reconnects to the system, and system starts working again.

Figure 14(a) shows the power waveforms in the system. While DC system operates in mode 3, DC bus voltage is stable as seen in Figure 14(b). In this mode, battery unit supports the grid, and it discharges. Figure 14(c) and Figure 14(d) show this state. In mode 3, because the systems operates stable, output AC voltage is produced as seen in Figure 14(e).

In the simulation study, the deep charge level of the battery unit is set $70 \%$ of state-of-charge (SOC). When it drops down to set value, the inverter is stopped working as seen in Figure 14(e), and battery starts charging from PV panels. Whole produced power from PV panels is transferred to the batteries. As a result, the \%SOC value of battery unit starts increasing as seen in region 1 in Figure 14(d). During region 1 interval, DC-DC converter controller of battery unit regulates DC bus voltage while charging the battery unit. DC bus voltage regulation and battery current waveforms in this region can be seen in Figure 14(b) and Figure 14(c), respectively. Because the inverter is stopped, voltage of the load is interrupted as seen in Figure 14(e).

At the end of region 1, \%SOC value of battery unit increases to $70.1 \%$. This value is set as reconnection value of the load in the control algorithm. The load is detached from the system when battery \%SOC value decreases to $\% 70$, and it reattaches when \%SOC value reaches to \%70.1 at the end of region 1. After this operating interval, the inverter starts feeding the load in region 2 as seen in Figure 14(a). The voltage of the load variations in transitions are seen in Figure 14(f). The voltage is regulated fast in disconnection and reconnection. As the PV power is the same in region 1 and region 2, battery charge current decreases because of increasing of load power.

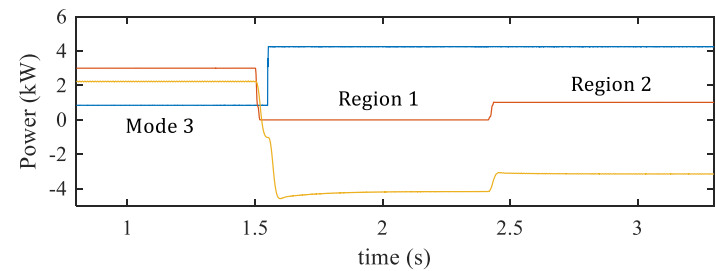

(a)

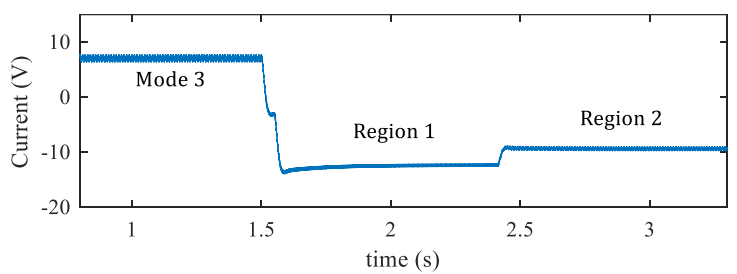

(c)

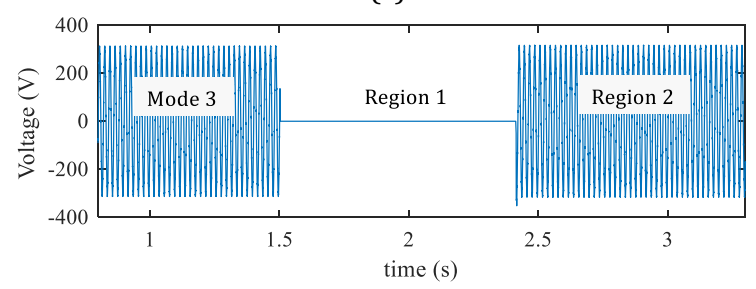

(e)

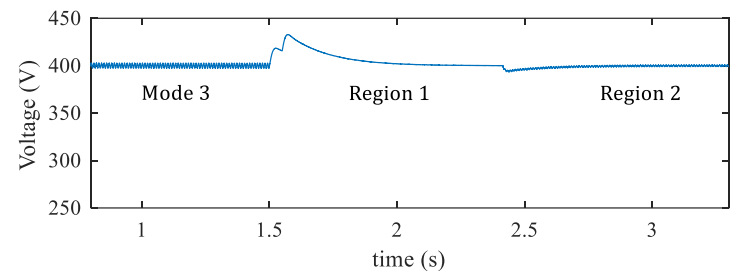

(b)

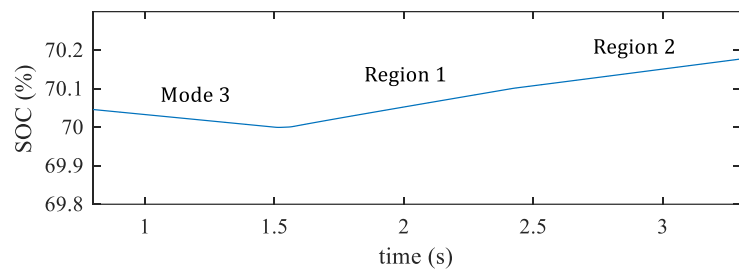

(d)
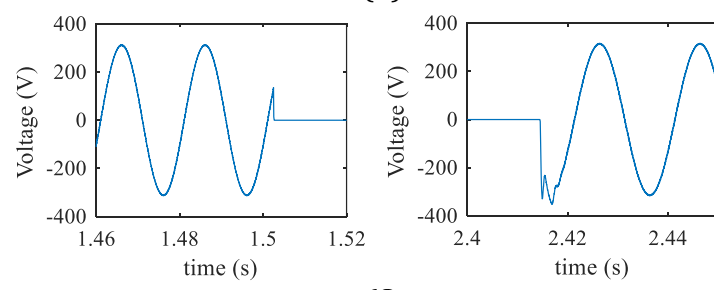

(f)

Figure 14. Mode 4 electrical quantities variations (a): Power variations of the system (blue: PV power, red: load power, yellow: battery power), (b): DC bus voltage, (c): Battery current, (d): State-of-charge of battery unit, (e): Voltage of the load,

(f): Voltage of the load in transitions 


\section{Conclusion}

In this study, a simulation of a standalone photovoltaic system with a power of $4.2 \mathrm{~kW}$ has been carried out, and five different operating modes have been examined. In the system, in which the P\&O maximum power point tracking algorithm is used, 20 panels with $215 \mathrm{~W}$ power are used. Batteries are used as storage unit in the system, and the power flow of battery unit is controlled by a DC-DC converter. Therefore, DC bus regulation is provided. A single phase full-bridge inverter is used to feed the load in the grid-independent system. Different five operating modes have emerged depending on the power generated from photovoltaic panels, load power demand and battery charge status. In mode 1, PV power feeds the load and battery unit because it is higher than load power, and battery unit voltage is in working range. The case that the load power is higher than the PV power is defined as mode 2. Therefore, the battery unit discharges and supports the PV panels to feed the load. In mode 3, PV power drops to zero, and therefore the load is fed by only battery unit. It makes the batteries discharge fast. In the case that the PV power is considerably higher than the load power in long time, the batteries are overcharged. Therefore, PV panels are disconnected from the system, and the load is fed only by batteries to decrease the battery voltage level. The batteries are reconnected to the system when the voltage drops to reconnection level. The last examined mode is mode 5 . The battery unit is fully discharged in the mode because the load power is higher than the produced PV power for a long time. As PV panel output power fluctuates because of weather conditions, it not convenient to feed the load only by panels. Therefore, the inverter stops working, and the load power is interrupted until the battery voltage level reaches to the reconnection level. PV panel charges the batteries, and they are reconnected to the system when the voltage reaches to the reconnection voltage set value. The performance of the developed system has been demonstrated by testing the energy flow of the system, and the control algorithms of the converters in five different operating modes. The control algorithms of the converters, and energy management strategy are verified by the simulation results. They can be used in standalone photovoltaic systems.

\section{Conflict of Interest}

No conflict of interest was declared by the authors.

\section{References}

Al-Waeli, A.H., Mahdi, H.F., 2017. Standalone PV systems for rural areas in Sabah, Malaysia: Review and case study application. International Journal of Computation and Applied Sciences, 2(1), 41-45.

Arikan, O., Isen, E., Kekezoglu, B., 2019. Performance analysis of stand-alone hybrid (wind-photovoltaic) energy system. Pamukkale Üniversitesi Mühendislik Bilimleri Dergisi, 25(5), 571-576.

Bayrak, G., Lebeli, M., 2011. A PV based automation system for fish farms: An application study. 2011 7th International Conference on Electrical and Electronics Engineering (ELECO), 1-5.

Çubukçu, M., Çolak, M., 2013. Gökçeada'da şebekeden bağımsız bir fotovoltaik güç sisteminin benzetimi ve karşılaştırmalı gerçek performans incelemesi. Pamukkale Üniversitesi Mühendislik Bilimleri Dergisi, 19(5), 201-208.

Durusu, A., Erduman, A., Yildiz, F., 2020. Comparative Study of Photovoltaic Array Optimum Tilt Angle and Orientation with Multi-Objective Consideration. Journal of Engineering Sciences and Design, 8(4), 1031-1041.

Gaurav, S., Birla, C., Lamba, A., Umashankar, S., Ganesan, S., 2015. Energy Management of PV - Battery based Microgrid System. Procedia Technology. 21, 103-111.

IEA., 2020. Snapshot of Global PV Markets 2020. International Energy Agency, Paris, France, 2020.

Isen, E., Bakan, A.F., 2018. Highly efficient three-phase grid-connected parallel inverter system. Journal of Modern Power Systems and Clean Energy, 6, 1079-1089.

Isen, E., Kochan, O., 2020. Fotovoltaik Panelin Tek Diyotlu Modellenmesi. Journal of Engineering Sciences and Researches. 2(1), 1-10.

Isen, E., Sengul, A., 2020. Comparison of Maximum Power Point Tracking Techniques on Photovoltaic Panels. Çanakkale Onsekiz Mart University Journal of Graduate School of Natural and Applied Sciences. 6(1), 14-29.

Jayachandran, M., Ravi G., 2019. Predictive power management strategy for PV/battery hybrid unit based islanded AC microgrid. Electrical Power and Energy Systems. 110, 487-496.

Kekezoglu, B., Arikan, O., Erduman, A., Isen, E., Durusu, A., Bozkurt, A., 2013. Reliability Analysis of Hybrid Energy Systems: Case Study of Davutpasa Campus, IEEE EuroCon, 1141-1144

Kouro, S., Leon, J.I., Vinnikov, D., Franquelo, L.G., 2015. Grid-Connected Photovoltaic Systems: An Overview of Recent Research and Emerging PV Converter Technology. IEEE Industrial Electronics Magazine, 9(1), 47-61.

Melo H.N., Trovao J.P.F., Pereirinha G., Jorge H.M., Antunes C.H., 2018. A Controllable Bidirectional Battery Charger for Electric Vehicles with Vehicle-to-Grid Capability. IEEE Transactions on Vehicular Technology, 67(1), 114-123.

Najeeb, M., Fahad H., Abdulhafedh Y., Mohammed H.G., Mahmood A., 2017. An Improved PI-Multistart Control Algorithm for Standalone PV Inverter System. International Journal of Renewable Energy Research, 7(4), 2085-2091.

Naktamna, P., Buasri, P., Taweepworadej, W., 2020. A Photovoltaic System for a Farm in Khon Kaen Province. 2nd International Conference on Advanced Research in Applied Science \& Egineering, 1-8.

Rasedul, H., Mekhilef, S., 2017. Highly efficient flyback microinverter for grid-connected rooftop PV system. Solar Energy, 146, 511-522. 
Sunarya, Syahrihaddin. A., Imfianto, P.S., 2019. Solar Energy for a Traditional Coastal Fishing Platform. Journal of Marine Science and Application, 18, 366-371.

Tarabsheh, A.A., Akmal, M., Ghazal, M., 2017. Series Connected Photovoltaic Cells-Modelling and Analysis. Sustainability, 9(371), 1-9. 